\title{
Misoprostol and teratogenesis in neonates
}

\author{
Mariana Beatriz Scabora da Silva ${ }^{1}$, Aline de Assis Ferreira ${ }^{1}$, \\ Soraya Ferreira Habr ${ }^{1,3}$, Maria Martha Bernardi ${ }^{1,2}$
}

\author{
${ }^{1}$ Department of Patology, Institute of Health Sciences, Paulista University, ${ }^{2}$ Department of Pathology, \\ Faculty of Veterinary Medicine and Zootechnics, University of São Paulo, Department of Pharmacology, \\ ${ }^{3}$ Department of Pharmacology, Institute of Biomedical Sciences, University of São Paulo
}

\begin{abstract}
This paper is focused in some aspects of maternal exposure to misoprostol during perinatal period, and the abortive and teratogenesis effects on the fetus. The causes of malformations were revised, taking into account chemical, physical and environmental factors as well as the interaction between them. There are evidences that the practice of abortion tripled in Southern and Northeastern Brazil in 15 years, and one of the most frequent forms of abortion is through the use of misoprostol. In Brazil, 1991, 288,700 women were hospitalized as a consequence of complications induced by abortion attempt with this medicine. This fact resulted in the ban of misoprostol across our country, by Decree 344/98 determined by the Health Ministry. The use of misoprostol requires special control and it is allowed only in hospitals, with supervision of the municipal health surveillance. Among the more severe problems affecting the non-aborted child is the injury on the central nervous system, which frequently results in the Moebius syndrome. This is a congenital and non-progressive paralysis of the VI and VII cranial nerves, frequently bilateral, which produces a unexpressive facial appearance and convergent Strabismus. Even banned in our country, abortion is illegally practiced, being deprived of proper knowledge about misoprostol teratogenic effects on the fetus as well as the risks involving mothers.
\end{abstract}

Uniterms: Perinatal toxicology. Misoprostol. Malformations. Moebius syndrome. Abortion. Cytotec ${ }^{\circledR}$.

Este trabalho enfoca aspectos relativos à exposição ao misoprostol no período perinatal como abortificante e agente teratogênico, assim como as causas das malformações, considerando-se fatores químicos, físicos e ambientais. A prática do aborto triplicou nas regiões Sul e Nordeste em 15 anos, sendo que entre os métodos mais freqüentes está o uso do medicamento com o princípio ativo do misoprostol. Em 1991 no Brasil, 288.700 mulheres foram socorridas em hospitais devido a complicações por indução de aborto com este medicamento. Isso resultou na proibição do misoprostol em todo país por determinação da portaria 344/98 do Ministério da Saúde, que exige um controle especial, onde sua utilização é permitida apenas em hospitais e com supervisão da vigilância sanitária municipal. Um dos problemas mais graves que a criança não abortada apresenta é uma injúria em seu sistema nervoso central desenvolvendo a Síndrome de Moebius. Esta é uma paralisia congênita e não progressiva do VI e do VII nervos cranianos, freqüentemente bilateral, que produz uma aparência facial pouco expressiva e estrabismo divergente. Neste sentido, mesmo sendo proibido em nosso país, o aborto induzido por misoprostol é praticado ilegalmente e sem uma verdadeira instrução da paciente sobre os efeitos teratogênicos do mesmo para ela e para seu bebê.

Unitermos: Toxicologia perinatal. Misoprostol. Malformações. Síndrome de Moebius. Aborto. Cytotec ${ }^{\mathbb{R}}$. 


\section{INTRODUCTION}

\section{Abortion and teratogenesis}

Along the history of many people, the presence of abnormalities in animals or children has received different interpretations; from the deification of individuals up to their complete rejection (Bernardi, Górniak, 2006).

In 1960, when the thalidomide, a sedative hypnotic drug used to treat nausea and vomiting during pregnancy, was recognized as the cause of a tragedy(Sanseverino et al., 2001), necessary attention was finally given to the effects of several environmental agents and/or exposure to chemicals during the perinatal period. In Germany and other countries, the use of thalidomide was responsible for numerous cases of a rare teratogenesis, the phocomelia. This teratogenesis is characterized by the reduction of members associated with other anomalies such as mental retardation, congenital heart disease, and renal, intestinal and ocular anomalies (McBride, 1991; Bernardi, Górniak, 2006).

Until that time, the toxicity tests required for the release of a drug by the Regulatory agencies included only studies in a single generation and only one species, usually a rodent (rats or mice). This procedure was the cause of the thalidomide tragedy. In fact, although the perinatal toxicity tests have been performed with this drug, the experimental animal employed was the rat, which is not sensitive to thalidomide teratogenic effects, unlike the mice (McBride, 1991).

From these events, Regulatory Agencies responsible for drugs release began to require more complex perinatal tests performed in multigenerational studies of, at least, three animal species, and at least one non-rodent (Niebyl, 1983).

Another important fact is that for the drugs testing, different doses should be used, including concentrations of three to five times higher than the therapeutic dose, and not generally used in studies to measure the effectiveness, such as the so called 'maximum tolerated dose' (MTD) (WHO, 1981).

The World Health Organization (WHO) adopted a broader definition of pharmacovigilance, and currently promotes a policy of rational use of drugs through various programs, such as the Drug Action Program on Essential Drugs and Vaccines (DAP). This program covers the need for constant evaluation of all aspects of cases involving drugs, the need for quality of drug therapy by health professionals, and the patients' and community responsibility in the process of pharmacovigilance (WHO, 1981).

The main objective is the establishment of policies and strategies for a rational use, involving the regulation of advertising and the development of effective systems of information on medicines. Still, the need to correctly establish the following requirements for medications use and dose period, ensures medications quality, safety and efficacy (Osorio-de-Castro et al., 2004).

Thus, the drug, studied just before the clinical pharmacology and therapeutic tool, has an interest in the epidemiology, involving the extent of use in populations and the detection of risk associated with their use. These studies are a valuable weapon for the quality assessment of care provided to a community by government (Osoriode-Castro et al., 2004).

In this sense, the development of animals can be affected by pathological, chemical and environmental agents. Thus, among the pathological factors, one can mention: 1) the heredity caused by inheritance of genes and chromosomal combinations that result in defects related to sex or not, determining a higher incidence of malformation in offspring, 2) maternal or fetal disease, for example, toxoplasmosis, hyperthermia, cytomegalovirus, producing teratogenesis and even fetal death. Respecting chemical factors, medicines, pollutants and pesticides are important in medicine. Moreover, environmental factors include the variables nutrition, physical factors and stress (Bernardi, Górniak, 2006).

\section{Perinatal death}

The term "perinatal death" was proposed by Peller in 1940 that thought must obtain statistical data of children born dead and those dying after the first week neonatal (Laurenti, Buchalla, 1985).

To understand the causes of infant mortality, it is necessary first to know the causes of perinatal mortality. Through variables such as maternal age, smoking status, prenatal care, previous pregnancies, birth order and birth weight, the maternal factors fetal and maternal-fetal and environmental were evaluated (Laurenti, Buchalla, 1985).

The passage of drugs from maternal blood to the embryo / fetus during pregnancy will depend mainly on the type of placentation, the physicochemical properties of the agent and promoted by biotransformation placenta (Bernardi, Górniak, 2006).

Maternal disorders contribute considerably to harmful effects of drugs in the perinatal period. We must consider that maternal body presents pharmacokinetic changes induced by the pregnancy and type of placenta, different in different species, determines the degree of exposure of the concept to various substances (Chagas et al., 2007).

Therefore, to call a drug 'teratogenic' (from the Greek, Derati $=$ monster $)$, it should be able to increase 
the frequency of a functional or structural abnormality in the offspring of certain species, when administered to parents before conception or to mother in a critical period of pregnancy (Bernardi, Górniak, 2006).

\section{Selection of drugs for use during pregnancy}

Under certain conditions, it is necessary the use of drugs to treat symptoms or intercurrent diseases or pregnancy of their own. A list of drugs that are affecting the neonatal morphology and/or brain development and some of the toxic signs based on their pharmacological actions. The drugs were classified with clinical use in the following categories according to risk offered in pregnancy (Briggs et al., 1994).

Category A: Controlled studies in women showed no risk to the fetus in the first quarter of pregnancy (without evidence of risk in later quarters) and the possibility of fetal injury seems remote. It includes few drugs as multivitamins or prenatal vitamins, except for mega doses of them.

Category B: studies in animals showed no fetal risk, but there are no controlled studies in pregnant women, or had any adverse effect on animals (excluding decrease in fertility) and not confirmed in controlled studies in pregnant humans (and there is no evidence of risk in subsequent quarters). Include several classes of drugs of common use, such as penicillins.

Category C: Studies in animals have revealed adverse effects on the fetus (teratogenic or embryogenic, or both) and no controlled studies in women, or they are not available in women and in animals. It should only be given if the expected benefit justifies the potential risk to the fetus. Examples: fluoroquinolones, fluconazole, itraconazole and others.

Category D: There is evidence of risk to the human fetus, but the benefits of their use may justify the risk (e.g., if the drug is needed in situations of imminent risk of life or in case of serious illness, there are no more alternative medicines safe and effective). Carbamazepine is an example.

Category X: Studies in animals and humans have demonstrated fetal abnormalities or there is risk based on human experimentation, or both. The risk of use in pregnant women clearly outweigh any potential benefit. The drug is contraindicated in women who are or intend to become pregnant. Isotretinoin, that is indicated for the treatment of acne and can cause various neurological abnormalities, facial and cardiovascular abnormalities, is an example.

The best option in the clinical use of drugs during pregnancy is the use of drugs with longer experience of use. In fact, the largest clinical experience allows a better assessment of safety and even to change its teratogenic status, justifying this conduct (Briggs et al., 1994).

Koren et al. (1998) list choice and alternative medicines for use in specific situations in pregnancy. Fortunately, most products do not seem exert adverse effects on the fetus.

\section{Misoprostol}

Misoprostol is a synthetic prostaglandin E1, initially introduced in the market for the treatment of gastritis and peptic ulcer resulting from the use of non-hormonal antiinflammatory. Costumes marketed under the names of Cytotec ${ }^{\circledR}$ (Searle) and Protokos ${ }^{\circledR}$ (Hebron S/A), shown in the 80 's, when used during the first quarter of pregnancy can cause uterine contractions able to stop an early pregnancy (Feitosa et al., 2006). The same seems to be ineffective in $50 \%$ of cases. This fact is related to the number of tablets used, the route of use (oral, vaginal or oral and vaginal together), the gestational period and individual susceptibility (Cavalcante et al., 2005).

Misoprostol causes a transient drop in the circulation of the fetus that depends on the intensity in the vascular phenomenon, its time for action and the time of occurrence can cause most of the congenital anomalies (Moreira et al., 2001).

Used for induction of labor in cases of intra-uterine death and the fetus alive, prolonged pregnancies, preeclampsia, diabetes, restrictions on fetal size, or in cases of cervical unfavorable situation to achieve a success of $75 \%$ to $95 \%$ of cases, varying according to the method of administration (Feitosa et al., 2006). In laboratory animals, produces severe abnormalities when administered on the third day of pregnancy, called the deployment period (Moraes et al., 2000).

According to Moreira et al. (2001), estimates made from INAMPS (National Institute of Health Care Social Security) data and incomplete statistics on abortions in private clinics in South and Northeast show that the practice of abortion in these regions tripled in 15 years. Moreover, among the used resources there are more abortive teas, herbal infusions, medicinal and misoprostol. The use of misoprostol was found in attempts to abortion generally used when the dosage of 4 tablets, 2 oral (sublingual) and 2 vaginal (Moreira et al., 2001).

In 1991 in Brazil, 288,700 women were helped in hospitals because of complications in abortion induction with misoprostol. Its use can cause severe pain, heavy bleeding, nausea, vomiting and diarrhea and can increase the complications in proportion to the period of gestation (Rose et al., 2006). 
Cavalcante et al. (2005), reported in a study with 15 mothers of children diagnosed with Moebius Syndrome, which $66.7 \%$ of women attempted abortion with misoprostol by combined (oral and vaginal), and the average was 4 tablets , 8 per woman. The authors also reported that all women in the study made the attempt in the first three months of pregnancy.

Due to high occurrence of these cases, the sale of Cytotec ${ }^{\circledR}$ was prohibited throughout the country by decree 344/98 establishing the Ministry of Health, and its permitted use only in hospitals (Cavalcante et al., 2005).

The use of Cytotec $\AA$ is approved in hospitals for the induction of labor with immature cervix and alive fetus, it is considered as or more efficient than the natural prostaglandins and more efficient than the oxytocin. Feitosa et al. (2006) conduced studies concerning the induction of labor involving 40 women at high risk in two hospitalschools in the period July to December 2003. Resulting in a margin of $95 \%$ of deliveries in approximately 24 hours after its induction with misoprostol. The route usually used in these cases is sublingual what can be explained by the absence of first pass liver, and its almost neutral $\mathrm{pH}$ (Feitosa et al., 2006).

\section{The Moebius syndrome}

The Moebius syndrome is characterized by congenital and not Progressive palsy, of VI and VII pairs of cranial nerves, often bilateral, which produces a unexpressive facial appearance and divergent strabismus (Moebius, 1988). Other cranial nerves may be present committed (???), unilateral or bilateral, determining ptosis, deafness, disturbances of sensation in the territories innervated by the trigeminal, dysphagia, dysphonia and atrophy of the tongue, which can be found in different combinations (Cavalcante et al., 2005) .

Mental retardation is usual, suggesting the involvement of the nervous system, skeletal malformations occur in many cases, particularly characterized by the presentation of crooked feet. Micrognathia and aplasia of the pectoral are also observed and in this case are called Polland syndrome (Marti-Herrero et al., 1998). Other abnormalities have been described, such as defects of the extremities, teeth, heart and central respiratory dysfunction (Carneiro, Gomes, 2005).

The origin of the Moebius Syndrome is speculative, but certainly is influenced by genetic and environmental factors, and the fetal transient ischemia is the most accepted theory to explain the syndrome (Dotti et al., 1989, Volpe, 1995). Thus, any change that adversely affects the blood flow of the placenta to the fetus, in a time of ges- tation, could result in aplasia or hypoplasia of the facial nerve nuclei of the motor and external eye in the brainstem.

Although most cases are sporadic, some scholars suggest a genetic origin for the syndrome. Among them, Dotti et al. (1989) described evidence of dominant inheritance in two families and Ziter et al. (1977) recognized that the translocation between the short arm of chromosome 1 and the long arm of 13 were responsible for cases of Moebius syndrome in the same family. Environmental factors have been implicated in the genesis of Moebius Syndrome, such as hyperthermia, exposure of pregnant women to infection, use of misoprostol, alcohol, cocaine, thalidomide and the benzodiazepines, among others.

According to Carneiro and Gomes (2005), the Moebius syndrome is a rare disease, but their frequency has increased in our society because of the use of misoprostol in pregnant women.

Abortion is a very old method of birth control practiced by all civilizations, although it is recognized that in many countries it is banned in almost all Latin America, which does not prevent the illegal practice in Brazil (Moreira et al., 2005). The factors leading to this act are usually inadequate financial condition, domestic violence, a project of life, unemployment, numerous offspring, among others (Gesteira et al., 2006).

The abortion in Brazil is a public health problem, due to its high incidence. According to studies (SchulerFaccini et al., 2002), it is estimated that about $15 \%$ of recognized pregnancies end in abortion and that 3 to $5 \%$ of all newborns have a living congenital defect when coming from frustrated attempts to abortion .

The biggest problem currently is the interrelationship between the use of misoprostol as abortive that exposes the fetus and mother to numerous risks and sequelæ, one of which may be the increase in the number of cases of Moebius syndrome in newborns.

As a way of preventing the marketing of the drug, Cytotec $\AA$ was banned from the market being used only in hospitals (Cavalcante et al., 2005).

\section{CONCLUSIONS}

The abortion in Brazil is a public health problem, there is seen to its high incidence. One of the drugs most used for induction of illegal abortion is misoprostol. Besides the risks of maternal bleeding, the frequent development of teratogenesis in children exposed to misoprostol, in which there was no success in trying to abortion occurs. You need clarification of the pregnant women about the risk of abortion with the use of this product. It will be interesting to clarify all women of childbearing age about 
the risks of abortion and of contraceptive methods to avoid the use of medicines to end abortion.

\section{ACKNOWLEDGMENTS}

À Bióloga Patrícia Oliveira Moura e a Professora Érica P. Costa, pela revisão do assunto. Este trabalho é parte da monografia de conclusão de curso das alunas Mariana Beatriz Scabora da Silva e Aline de Assis Ferreira.

\section{REFERENCES}

BERNARDI, M. M.; GÓRNIAK, S. L. Sobre o uso de medicamento no período perinatal. In: Farmacologia aplicada a Medicina Veterinária. Rio de Janeiro: Ed. Spinosa, 2006. p.807-816.

BRIGGS, G. G.; FREEMAN, R. K.; YAFFE, S. J. Drugs in pregnancy and lactation. 4.ed. Baltimore, Williams \& Wilkins, 1994. 974p.

CAVALCANTE, R. B.; NOGUEIRA, M. B.; GIACHETI, C. M. Síndrome de Moebius relacionada ao uso do misoprostol (Cytotec) como abortivo. Rev. Bras. Prom. Saúde, v.18, n.3, p.140-144, 2005.

CARNEIRO, M. M. S.; GOMES, I. C. D. O Perfil morfofuncional oral de crianças portadoras da Síndrome de Moebiüs. Rev. CEFAC, São Paulo, v.7, n.1, p. 68-74, 2005.

CHAGAS, L. M.; BASS, J. J.; BLACHE, D.; BURKE, C. R.; KAY, J. K.; LINDSAY, D. R.; LUCY, M. C.; MARTIN, G. B.; MEIER, S.; RHODES, F. M.; ROCHE, J. R.; THATCHER, W. W.; WEBB, R. Invited review: New perspectives on the roles of nutrition and metabolic priorities in the sub fertility of high-producing dairy cows. J. Dairy Sci., v.90, n.9, p.4022-4032, 2007.

DOTTI, M. T.; FEDERIC, A. O.; PALMERI, S.; GUAZZI, G. C. Congenital oculo-facial paralysis (Moebius syndrome): evidence of dominant inheritance in two families. Acta Neurol., v.11, n.6, p.434-438, 1989.

FEITOSA, F. E. L.; AMORIM, M. M. R.; ALENCAR JUNIOR, C. A.; COUTINHO, I.; SAMPAIO, Z. S. Nova formulação do misoprostol sublingual na indução do trabalho de parto. Rev. Assoc. Med. Bras., v.52, n.4, p.251-255, 2006.

GESTEIRA, S. M. A.; BARBOSA, V. L.; ENDO, P. C. O. Luto no processo de aborto provocado. Revista Acta Paul. Enferm., v.19, n.4, p.462-467, 2006.
KOREN, G.; PASTUSZAK, A.; ITO, S. Drugs in pregnancy. $N$. Engl. J. Méd., v.338, n.16, p. 1128-1137, 1998.

LAURENTI, R., BUCHALLA C.M. Estudo da morbidade e da mortalidade perinatal em maternidades. Pública. Rev Saúde., v.19, p.225-232, 1985.

MARTI-HERRERO, M.; CABRERA-LOPEZ, J. C.; TOLEDO, L.; PÉREZ-CANDELA, V.; BONNET, D. Sindrome de Moebius: três formas diferentes de presentatión. Rev. Neurol., v. 27, p.975-978, 1998.

MOREIRA, L. M. A.; DIAS, A. L.; RIBEIRO, H. B. S.; FALCÃO, C. L.; FELÍCIO, T. D.; STRINGUETTI, C.; SANTOS, M. D. F. Associação entre o uso de abortificantes e defeitos congênitos. Rev. Bras. Ginecol. Obstet., v.23, n.8, p.517-521, 2001.

MOEBIUS, P. Ueber angeborene doppelseitige AbducensFacialis-Laehmung. Münch Med Wochenscher, v.35, n.3B, p.91-94, 1888.

MORAES, A. P.; HOSOMI, R. Z.; BERNARDI, M. M. Avaliação dos possíveis efeitos embriotóxicos do misoprostol $\left(\right.$ Cytotec $\left.{ }^{\circledR}\right)$ administrado no período gestacional de préimplantação (terceiro dia de gestação) a camundongos. Perspectivas Médicas, São Paulo, v.11, p.8-11, 2000.

MCBRIDE, W. G. Thalidomide and congenital abnormalities. Lancet, v.2, p.1358, 1962.

NIEBYL, J. R. O uso de drogas na gravidez. São Paulo: Roca, 1983. 211p.

OSORIO-DE-CASTRO, C. G. S.; PAUMGARTTEN, F. J. R.; SILVER, L. D. O uso de medicamentos na gravidez. Ciência \& Saúde Coletiva, v.9, n.4, p. 987-996, 2004.

ROSE, S. B.; SHAND, C.; SIMMONS, A. Mifepristone and misoprostol induced mid- trimester termination of pregnancy: A reniew of 272 cases. Aust. N. Z. J. Obstet. Gynaecol., v.46, n.6, p.479-485, 2006.

SANSEVERINO MTV, SPRITZER DT, SCHULER-FACCINI L. Manual de teratogênese. Porto Alegre: Editora UFRGS, 2001. p.16, 219, 262, 264-268, 485.

SCHULER-FACCINI, L.; LEITE, J. C. L; SANSEVERINO, M. T. V.; PERES R. M. Avaliação de teratógenos na população brasileira. Ciência \& Saúde coletiva, v.7, n.1, p.65-71, 2002. 
VOLPE, J. Neurology of the newborn. 3.ed. Philadelphia:

Saunders, 1995. p.43-92.
ZITER, F. A.; WISER, W. C.; ROBINSON, A. Three generations of a Moebius syndrome variant with chromosome translocation. Arch. Neurol., v.34, n.7, p. 437- 442, 1977.

Received for publication on $20^{\text {th }}$ December 2007 Accepted for publication on $6^{\text {th }}$ April 2009 